\title{
Antigenic Relationships Between Escherichia coli O Antigens O149 to O163 and Shigella O Antigens
}

\author{
B. ROWE, R. J. GROSS, AND M. GUINEY \\ Salmonella and Shigella Reference Laboratory, Central Public Health Laboratory, \\ London NW9 5 HT, England
}

\begin{abstract}
$\mathrm{O}$ antigens $\mathrm{O} 149$ to $\mathrm{O} 163$ are recent additions to the Escherichia coli antigenic scheme. Their antigenic relationships with Shigella serovars were examined. O antigen identity was demonstrated between $E$. coli $\mathrm{O} 149$ and Shigella boydii 1 and between $E$. coli $\mathrm{O} 152$ and provisional Shigella serovar 3341-55. A reciprocal relationship was found between $E$. coli $\mathrm{O} 159$ and Shigella dysenteriae 4 but identity was not demonstrated. The remaining $E$. coli $\mathrm{O}$ antigens were not significantly related to any Shigella serovar.
\end{abstract}

There is extensive sharing of antigenic components throughout the Enterobacteriaceae, and numerous examples exist between Shigella and Escherichia coli serovars. Some Shigella O antigens are identical to $E$. coli $\mathrm{O}$ antigens whereas in other instances the antigens are closely related but not identical.

In 1950 Veazie (11) described $\mathrm{O}$ antigen relationships between Shigella boydii 4 and $E$. coli O53 and between $S$. boydii 5 and $E$. coli O79. Kauffmann (4) confirmed these findings and demonstrated that the $\mathrm{O}$ antigens were identical in each of these pairs. In 1953 Piechaud (10) showed the $\mathrm{O}$ antigen identity of $S$. boydii 11 with $E$. coli O105ab.

In 1972 Edwards and Ewing (1) reported that, with only two exceptions, the $\mathrm{O}$ antigens of all Shigella serovars were related to one or more of the $\mathrm{O}$ antigens of $E$. coli $\mathrm{O}$ groups 1 to 148 . Furthermore the $\mathrm{O}$ antigens of 13 Shigella serovars were identical to one or other of these $E$. coli $\mathrm{O}$ antigens.

Since 1968, antigens 0149 to 0163 have been added to the antigenic scheme for $E$. coli. This study reports their antigenic relationships to established and provisional Shigella serovars.

Bacterial strains. $E$. coli $\mathrm{O}$ antigens 154, 155, $156,158,159,160$, and 161 were originally characterized at the Salmonella and Shigella Reference Laboratory (SSRL) and test strains from the laboratory collection were used. Test strains for $O$ antigens $149,150,151,152,153$, 157,162 , and 163 were obtained from the Collaborative Centre for Reference and Research on Escherichia (World Health Organization). The full serovar and a reference to the descriptive literature of each of the 15 strains is shown in Table 1.

Test strains for all accepted Shigella serovars (1) and provisional serovars 3873-50, 2000-53, $3341-55,3615-53,2710-54,2044-54$, and 1621-
54 (2) were present in the SSRL culture collection.

Preparation of antisera. $O$ antigen suspensions were prepared from all the strains by harvesting the growth from two nutrient agar slopes into $0.9 \%$ saline and heating to $100 \mathrm{C}$ for $2.5 \mathrm{~h}$. After centrifugation, the heated organisms were resuspended in $15 \mathrm{ml}$ of saline and commercial formalin was added to a final concentration of $0.3 \%$. Rabbits were immunized by intravenous injections of $0.5,1.0,2.0,2.0$, and $2.0 \mathrm{ml}$ of suspension at 5-day intervals; $40 \mathrm{ml}$ of blood was taken 5 and 10 days after the final injection, and the rabbits were exsanguinated 5 days later. The products of all three bleedings were pooled.

$O$ antigen suspensions for agglutination tests. $\mathrm{O}$ antigen suspensions for agglutination tests were prepared by heating overnight broth cultures at $100 \mathrm{C}$ for $30 \mathrm{~min}$. Commercial formalin was added to a final concentration of $0.3 \%$

Agglutination tests. Agglutination tests were performed in plastic agglutination trays and were incubated at $50 \mathrm{C}$ for $16 \mathrm{~h}$.

O antisera for $E$. coli $0149-0163$ were tested against the $\mathbf{O}$ antigen suspensions of all the Shigella strains, and $\mathrm{O}$ antigen suspensions of $E$. coli $0149-0163$ were tested against $\mathrm{O}$ antisera for all the Shigella strains.

Absorption studies. Where cross-reactions were found, reciprocal absorptions were performed to determine the relationships between the strains.

Serological cross-reactions were considered significant only if the cross-reaction titer was greater than or equal to one-sixteenth of the homologous titer. Significant cross-reactions were found between certain Shigella serovars and $E$. coli O149, O152, and O159 (Tables 2, 3 and 4$)$, but the remaining $E$. coli strains 
TABLE 1. Antigenic relationships between Escherichia coli $O$ antigens 149-163 and Shigella serovars

\begin{tabular}{|c|c|c|c|c|}
\hline $\begin{array}{l}\text { Original ref- } \\
\text { erence no. }\end{array}$ & Original source & $\begin{array}{c}\text { Refer- } \\
\text { ence to } \\
\text { litera- } \\
\text { ture }\end{array}$ & Serovar & Relationship \\
\hline CS1483 & Enteric disease in piglets, Ireland & 9 & O149.K91.K88ac.H1O & $\begin{array}{l}\text { S. boydii } 1 \text { (identical) } \\
\text { S. dysenteriae } 2(\mathrm{a}, \mathrm{b}-\mathrm{a}, \mathrm{c}) \\
\text { S. boydii } 4 \text { (one way) }\end{array}$ \\
\hline 1935 & Diseased chickens, England & 3 & O150.K93.H6 & None \\
\hline $880-67$ & $\begin{array}{l}\text { Gastroenteritis in adults and chil- } \\
\text { dren, Japan }\end{array}$ & 5 & O151.K?H50 & None \\
\hline $1184-68$ & $\begin{array}{l}\text { Dysentery-like disease in adults } \\
\text { and children, Japan }\end{array}$ & 5 & O152.K?H- & $\begin{array}{l}\text { Provisional serovar } 3341-55 \\
\text { (identical) }\end{array}$ \\
\hline 14097 & Infantile diarrhea, Grermany & 5 & O153.K?H7 & None \\
\hline E1541/68 & $\begin{array}{l}\text { Human feces and food, Arabian } \\
\text { Gulf }\end{array}$ & 7 & O154.K94.H4 & None \\
\hline E1529/68 & $\underset{\text { Gulf }}{\text { Human feces and food, Arabian }}$ & 7 & O155.K?H9 & None \\
\hline E1585/68 & $\begin{array}{l}\text { Human feces and food, Arabian } \\
\text { Gulf }\end{array}$ & 7 & O156.K?H47 & None \\
\hline A2 & Enteric disease in piglets, Ireland & 3 & O157.K88ac.H19 & None \\
\hline E1020/72 & Infantile diarrhea, England & 8 & O158.K?H20 & None \\
\hline E2476/72 & Infantile diarrhea, Scotland & 8 & O159.K?H23 & S. dysenteriae $4(\mathrm{a}, \mathrm{b}-\mathrm{a}, \mathrm{c})$ \\
\hline E110/69 & $\begin{array}{l}\text { Human feces and food, Arabian } \\
\text { Gulf }\end{array}$ & 8 & O160.K?H34 & None \\
\hline E223/69 & Human feces, Arabian Gulf & 8 & O161.K?H54 & None \\
\hline $10 \mathrm{~B} 1 / 1$ & Human feces, England & 6 & O162.K?H10 & None \\
\hline SN3B/1 & Human feces, England & 6 & O163.K?H19 & None \\
\hline
\end{tabular}

TABLE 2. Antigenic relationships between Escherichia coli O149 and Shigella serovars

\begin{tabular}{|c|c|c|c|c|c|}
\hline \multirow{2}{*}{ Serum } & \multirow{2}{*}{ Absorbed with } & \multicolumn{4}{|c|}{ Agglutination titer of $\mathrm{O}$ antigen suspension } \\
\hline & & O149 & S. dysenteriae 2 & S. boydii 1 & S. boydii 4 \\
\hline \multirow[t]{4}{*}{ O149 } & Nil & 25,600 & 200 & 12,800 & 3,200 \\
\hline & S. dysenteriae 2 & 25,600 & $<100$ & 12,800 & 1,600 \\
\hline & S. boydii 1 & $<100$ & $<100$ & $<100$ & $<100$ \\
\hline & S. boydii 4 & 25,600 & $<100$ & 6,400 & $<100$ \\
\hline \multirow[t]{2}{*}{ S. dysenteriae 2} & $\mathrm{Nil}$ & 1,600 & 25,600 & 6,400 & $<100$ \\
\hline & O149 & $<100$ & 25,600 & $<100$ & $<100$ \\
\hline \multirow[t]{2}{*}{ S. boydii 1} & Nil & 1,600 & $<100$ & 3,200 & $<100$ \\
\hline & O149 & $<100$ & $<100$ & $<100$ & $<100$ \\
\hline \multirow[t]{2}{*}{ S. boydii 4} & Nil & $<100$ & $<100$ & $<100$ & 3,200 \\
\hline & 0149 & $<100$ & $<100$ & $<100$ & 25,600 \\
\hline
\end{tabular}

TABLE 3. Antigenic relationships between Escherichia coli 0152 and Shigella serovars

\begin{tabular}{clrr}
\hline \multirow{2}{*}{ Serum } & $\begin{array}{c}\text { Absorbed } \\
\text { with }\end{array}$ & \multicolumn{2}{c}{$\begin{array}{c}\text { Agglutination titer of O an- } \\
\text { tigen suspension }\end{array}$} \\
\cline { 3 - 4 } & & \multicolumn{1}{c}{0152} & \multicolumn{1}{c}{3341.55} \\
\hline \multirow{2}{*}{ 152 } & Nil & 12,800 & 25,600 \\
& $3341-55$ & $<100$ & $<100$ \\
$3341-55$ & Nil & 12,800 & 25,600 \\
& O152 & $<100$ & $<100$ \\
\hline
\end{tabular}

showed no significant cross-reactions with any Shigella serovars.

Reciprocal absorptions showed that the $\mathrm{O}$ antigen of $E$. coli 0149 was identical to that of $S$. boydii 1 . The test strain of $E$. coli O149 also
TABLE 4. Antigenic relationships between Escherichia coli O159 and Shigella serovars

\begin{tabular}{llrr}
\hline Serum & Absorbed with & $\begin{array}{c}\text { Agglutination } \\
\text { titer of O anti- } \\
\text { gen suspension }\end{array}$ \\
\cline { 2 - 4 } & & \multicolumn{3}{c}{$\begin{array}{c}\text { S. dysen- } \\
\text { teriae } \\
\end{array}$} & & & 4 \\
\hline O159 & Nil & 1,600 & 400 \\
& S. dysenteriae 4 & 800 & $<100$ \\
S. dysenteriae 4 & Nil & 200 & 25,600 \\
& O159 & $<100$ & 25,600 \\
\hline
\end{tabular}

showed a reciprocal relationship of the a,b-a,c variety with the test strain of $S$. dysenteriae 2 . The test strain of $S$. boydii 4 was agglutinated 
by $E$. coli $\mathrm{O} 149$ antiserum, but the reciprocal reaction was not found.

The $\mathrm{O}$ antigen of $E$. coli $\mathrm{O} 152$ was identical to that of provisional Shigella serovar 3341-55, and $E$. coli 0159 showed a small reciprocal relationship of the a,b-a,c variety with $S$. dysenteriae 4.

The antigenic relationships found are summarized in Table 1.

The first stage in the identification of Enterobacteriaceae is the determination of genus or species by means of biochemical tests. Within these biochemically defined taxa, serological analysis provides more precise identification.

Biochemically atypical strains occur in several genera, and these strains can resemble members of other genera so closely that errors in identification may arise. There is no problem in differentiating biochemically typical $E$. coli from shigellas. However, if only a limited range of biochemical tests is used, nonmotile, anaerogenic, and lactose-negative strains of $E$. coli may be suspected of being shigellas. This is particularly likely to occur if the strain is strongly agglutinated by antiserum for Shigella. The problem can be resolved by the use of tests for lysine-decarboxylase, $\beta$-galactosidase, and Christensen citrate and by remembering that Shigella species are much less active against sugars than is $E$. coli.

The systematic study of biochemical characters is essential in the differentiation of genera, but it is useful to be aware of the intergeneric relations of antigens within the Enterobacteriaceae.

\section{REPRINT REQUESTS}

Address reprint requests to: Dr. B. Rowe, Salmonella and Shigella Reference Laboratory, Central Public Health Laboratory, Colindale Ave., London NW9 5HT, England.

\section{LITERATURE CITED}

1. Edwards, P. R., and W. H. Ewing. 1972. Identification of Enterobacteriaceae. Burgess Publishing Company, Minneapolis.

2. Ewing, W. H., R. W. Reavis, and B. R. Davis. 1958. Provisional Shigella serotypes. Can. J. Microbiol. 4:89-107.

3. Furowicz, A. J., and F. Ørskov. 1972. Two new Escherichia coli $\mathrm{O}$ antigens, $\mathrm{O} 150$ and $\mathrm{O157}$, and a new $\mathrm{K}$ antigen, $\mathrm{K} 93$, in strains isolated from veterinary disease. Acta Pathol. Microbiol. Scand. 80:441-444.

4. Kauffmann, F. 1954. Enterobacteriaceae, Ejnar Munksgaard, Copenhagen.

5. Orskov, F., I. Orskov, and A. J. Furowicz. 1972. Four new Escherichia coli $\mathrm{O}$ antigens: O148, O151, 0152 and 0153 , and one new $H$ antigen: H50, found in strains from enteric diseases in humans. With a discussion on the future numbering of $K$ antigens. Acta Pathol. Microbiol. Scand. 80:435-440.

6. Orskov, I., F. Orskov, K. A. Bettelheim, and M. E. Chandler. 1975. Two new Escherichia coli $O$ antigens, $\mathrm{O} 162$ and $\mathrm{O} 163$, and one new $\mathrm{H}$ antigen, H56: withdrawal of $\mathbf{H}$ antigen H50. Acta Pathol. Microbiol. Scand. 83B:121-124.

7. Ørskov, I., F. Ørskov, and B. Rowe. 1973. Three new Escherichia coli $O$ antigens 0154,0155 and 0156 , and one new $\mathrm{K}$ antigen, K94. Acta Pathol. Microbiol. Scand. 81:59-64.

8. Ørskov, I., F. Ørskov, and B. Rowe. 1975. Four new Escherichia coli $\mathrm{O}$ antigens, O158, O159, O160 and O161, and two new H antigens, H53 and H54. Acta Pathol. Microbiol. Scand. 83B:116-120.

9. Ørskov, I., F. Ørskov, W. Wittig, and E. J. Sweeney. 1969. A new $E$. coli serotype O149: K91(B), K88ac(L): $\mathrm{H} 10$ isolated from diseased swine. Acta Pathol. Microbiol. Scand. 75:491-498.

10. Piechaud, M. 1953. Sur un paracolobactrum possédant l'antigène somatique du type provisoire $S h$. boydii 11 et de Escherichia coli O105. Ann. Inst. Pasteur Paris 85:496-499.

11. Veazie, L. 1950. Antigenic identity of Shigella alkalescens type 1 and Kauffmann's Escherichia O group 1. Proc. Soc. Exp. Biol. Med. 74:350-352. 